\title{
Anti-CDH6 Antibody-drug Conjugate HKT288
}

National Cancer Institute

\section{Source}

National Cancer Institute. Anti-CDH6 Antibody-drug Conjugate HKT288. NCI Thesaurus.

Code C131439.

An immunoconjugate consisting of a human monoclonal antibody directed against the tumor-associated antigen (TAA) cadherin-6 (CDH6; CDH-6) conjug ated to a maytansinebased cytotoxic agent, with potential antineoplastic activity. The monoclonal antibody moiety of HKT 288 targets and binds to CDH6 located on tumor cell surfaces. After internalization, the maytansine moiety binds to tubulin, which disrupts microtubule assembly/disassembly dynamics and inhibits both division and proliferation of CDH6expressing tumor cells. CDH6, a member of the cadherin family and overexpressed by a variety of cancers, plays a key role in tumor cell proliferation. 